DOI https://doi.org/10.30525/978-9934-26-045-2-24

\title{
ЗАГАЛЬНІ ТЕНДЕНЦЇ̈ ВИКОРИСТАННЯ ПОЗИТИВНОГО ЗАРУБІЖНОГО ДОСВІДУ ПУБЛІЧНОГО УПРАВЛІННЯ В УКРАЇНІ
}

\author{
Пержун В. В. \\ кандидат соиіологічних наук, доиент, \\ доиент кафедри філософіі та культурологіі \\ Чернівецького начіонального університету імені Юрія Федьковича, \\ м. Чернівиі, Україна, \\ докторант \\ Національної академії державного управління \\ при Президентові України \\ м. Київ, Украӥна
}

Все більша вагомість інформаційних мереж, кардинальні світові зміни, зрушення, трансформації спонукають до розуміння, що сучасний розвиток будь-якої науки не можливий в обмеженому, замкнутому просторі однієї країни. 3 огляду на це поглиблюється «обмін науковими досягненнями та рух ідей, які вимагають урахування теоретичних здобутків усіх країн» [2, с. 18]. Зрозуміло, що відмовлятись від своїх національних традицій у галузі управління не потрібно, особливо це стосується емпіричних досліджень, які показують найбільш вразливі внутрішні проблеми розвитку суспільства і потребують результативного вирішення. Але й тут знайти правильні шляхи реформування структурних елементів управління вимагає впровадження позитивного зарубіжного досвіду, позаяк такий підхід сприятиме розробці новітніх як теоретико-методологічних, так і практичних засад публічного управління. Вчитися й переймати позитивний досвід ніколи не пізно. Свого часу, один з відомих представників теоретичного і практичного управління В. Вільсон зауважував: «Ми ніколи не зможемо оцінити ні наші достоїнства, ні наші слабкості, порівнюючи себе з собою. Ми нічого не дізнаємося про себе, поки будемо знати тільки себе» [1, с. 41]. У своїй праці «Наука державного управління» він писав: «... демократичні принципи потрібно поєднувати 3 технічними прийомами управління, які опрацьовані на досвіді європейських, у тому числі й монархічних держав, оскільки демократичне управління, засноване тільки на прагматичному досвіді, без науки управління, не здатне 
створити управлінський апарат, відповідний завданням суспільного розвитку, які стають усе складнішими» [1, с. 40]. Такий підхід актуальний сьогодні для України не дивлячись, що пройшло вже більше ста років. Тому, українські дослідники все більше уваги починають приділяти проблемам запровадження позитивного зарубіжного досвіду у систему публічного управління в Україні. Серед них варто назвати: Т. Безверхнюк, Н. Виноградову, В. Поліщука, Т. Кондратюка, С. Орлів, Л. Хашиєву, О. Хорошенюка, В. Гриба, Н. Котовську, А. Рачинського та ін.

Враховуючи позитивний досвід зарубіжних країн у публічному управлінні, необхідно визначити пріоритетні напрями й основні завдання, що допоможуть забезпечити його використання в Україні. Сьогодні ми вступаємо у фазу управлінських реформ, коли практично має проявитися нова модель державного менеджменту, що буде вироблятися за допомогою сучасних управлінських технологій, принципів, форм і методів нового публічного врядування. Звідси, постають завдання всебічного дослідження зарубіжного практичного досвіду з таких напрямів:

- методика визначення і опис державних посад, їх розподіл на політичні і кар'єрні, підбір, розстановка, перепідготовка, підвищення кваліфікації та виховання кадрів, робота з кадровим резервом;

- впровадження та використання ефективних механізмів обмеження участі посадових осіб державної влади, політиківзаконодавців, публічних службовців у підприємницькій та інших сферах діяльності;

- методика створення кваліфікаційних характеристик, професіограм управлінців різних рівнів, публічних службовців, подальше удосконалення системи присудження рангів і кваліфікаційних розрядів;

- досвід складання реєстрів претендентів на державну службу, вироблення механізму відбору громадян на державну службу, формування державного замовлення на навчання персоналу, проведення конкурсів на заміщення державних посад i планування кар'єрного просування;

- порядок виходу у відставку і достойне пенсійне забезпечення;

- відповідна система фінансування державної (публічної) служби;

- питання оптимальної чисельності державного апарату, який би організаційно й територіально забезпечував управління державою;

- оптимізація форми оплати праці і контроль за доходами; 
- застосування антикорупційних заходів у галузі управління центральних органів влади і місцевого самоврядування;

- питання формування банків кадрової інформації та їх використання;

- форми взаємодії органів влади 3 науковими і навчальними закладами з питань державної служби, навчання майбутніх управлінців, науково-теоретичних і прикладних аспектів формування управлінської культури, організаційної культури, політико-правової культури і т. д. Про це, з нашими деякими доповненнями, пише український дослідник А. Рачинський [4, с. 19].

Найвідповідальнішою стратегією управлінських реформ в Україні залишається визначення, а в подальшій недалекій перспективі, впровадження результативних підходів до проблем вирішення важливих тактичних і стратегічних завдань успішної розбудови держави. Помітне місце у цій роботі мають займати керівний управлінський персонал, влада, політики, громадські організації, зрештою - публічні службовці, які $є$ авангардом практичної діяльності в управлінні. Для цього всі вони повинні оволодівати новітніми знаннями і передовим світовим досвідом державного (публічного) управління. Тут мова йде про основні управлінські ідеї й теорії, а також наявні практичні здобутки в державному управлінні країн Заходу. Їх є декілька і про них написано багато. Наприклад, на це звертає увагу у своїй публікації Т. Кондратюк [3].

Якщо Україна позиціонує себе з європейським вектором розвитку, то така євроінтеграція має охоплювати переважну більшість сфер життєдіяльності суспільства, а особливо публічне управління. Країни Свропейського Союзу (у подальшому СС) мають значний досвід проведення реформи державного управління та поступового утвердження норм і цінностей публічної політики. $Є$ декілька суттєвих загальновизнаних тенденцій публічного управління, які характерні для країн СС і вони мають також бути задіяні в Україні у процесах реформування державного менеджменту. Назвемо їх:

- відкритість управління для громадян;

- децентралізація сфери управління, надання реальних повноважень місцевому самоврядуванню: до прикладу, в Німеччині характерними елементами реформи децентралізації були: «дебюрократизація, дерегуляція, сервісне адміністрування, удосконалення систем контролю і підзвітності, реформування бюджетного процесу, посилення публічності і відкритості» [5]; 
- правове, організаційне i політичне становлення інституту місцевого самоврядування як практичне втілення реформи децентралізації;

- активна участь громад в управлінні, їх довіра до органів влади;

- підзвітність усіх гілок влади громадянам;

- результативність управлінської роботи, коли ефективна державна політика у сфері публічного адміністрування сприяє задоволенню здорових соціальних, економічних, культурних, побутових, матеріальних і духовних людських потреб;

- чітка, збалансована, прозора та якісна управлінська робота, яка є зрозумілою і відкритою для громадян;

- ефективне вдосконалення кадрової політики в управлінні, забезпечення центральних і місцевих органів влади компетентними працівниками;

- дієве формування управлінської, правової та організаційної культури керівних кадрів центрального управління, посадовців місцевих органів влади і публічних службовців.

Отже, сучасна українська дійсність вимагає від влади i громадянського суспільства вироблення і практичного застосування дійсно передових реформ направлених на системну зміну та реформування державного управління і введення основ публічного врядування, що засноване на тісній і плідній співпраці органів центральної влади та місцевого самоврядування. Це вимога часу. І в цій роботі важливе місце має займати вивчення і практичне впровадження позитивного зарубіжного досліду у галузі публічного управління. При цьому, ми не повинні сліпо копіювати такий досвід, а застосовувати його розумно i прагматично, враховуючи наші соціокультурні, національні, управлінські традиції, а також ментальні особливості.

\section{Література:}

1. Вильсон В. Наука государственного управления. Классики теории государственного управления: американская школа / под ред. Дж. Шпфритца, А. Хайда. Москва: Изд-во МГУ, 2003. 800 с.

2. Колодій А. Ф. Методологічне забезпечення науки «державне управління». Методологія наукових досліджень 3 державного управління: хрестоматія / упоряд.: С. В. Загородюк, О. Л. Свмешкіна, В. В. Лещенко; за заг. ред. К. Ю. Ващенка. Київ: НАДУ, 2014. С. 18-26.

3. Кондратюк Т. В. Зарубіжний досвід удосконалення системи державного управління та шляхи його використання в Україні. Інвестиції: практика та досвід. 2010. № 3. С. 56-59. 
4. Рачинський А. П. Основні принципи вивчення зарубіжного досвіду у сфері державної служби. Публічне управління: шляхи розвитку. Матеріали науково-практичної конференції за міжнародною участю: у 2-х т. / наук. ред. Ю. В. Ковбасюка, С. А. Романюка, О. Ю. Оболенського. Київ: НАДУ, 2014. Т. 1. С. 18-20.

5. Хачатурян X. В. Переоріснтація державного управління на потреби громадян: нова європейська модель та Україна. Вісник Київського міжнародного університету (серія: «Міжнародні відносини»). 2009. № 8 [Електроний варіант]. Режим доступу: http://www.kymu.edu.ua/vmv/v/08/khachaturian.htm.

DOI https://doi.org/10.30525/978-9934-26-045-2-25

\title{
ПЕРЕЗАВАНТАЖЕННЯ АНТИКОРУПЦИЙНИХ ОРГАНІВ В УКРАЇНI
}

\author{
Пінчук В. I. \\ аспірант \\ Науковий керівник: Шевченко О. М. \\ кандидат економічних наук, дочент \\ Національного університету «Чернігівська політехніка» \\ м. Чернігів, Україна
}

У Міжнародний день боротьби 3 корупцією Антикорупційна Ініціатива $\mathrm{CC}$ в Україні (EUACI) відзначає зусилля спеціалізованих антикорупційних відомств. Зі створенням Національного антикорупційного бюро (НАБУ), Спеціалізованої антикорупційної прокуратури (САП) та Вищого антикорупційного суду (ВАКС) ефективне та незалежне переслідування корупціонерів стало реальністю в Україні. Впровадження системи електронного декларування забезпечило безпрецедентний рівень прозорості у державному секторі, а перезавантаження Національного агентства 3 питань запобігання корупції (НАЗК) призвело до посилення зусиль щодо запобігання корупції. Однак останнім часом успішний розвиток чинної антикорупційної інфраструктури знаходиться під загрозою і тиском. Це важкі часи для тих, хто працює в галузі боротьби з корупцією в Україні.

32017 року EUACI відіграє ключову роль у забезпеченні стійкого інституційного розвитку антикорупційних установ, у тому числі у 